\author{
Р.М. Джус ${ }^{1}$, М.Г. Стадніченко ${ }^{1}$, В.В. Попов ${ }^{2}$, С.А. Плешкунов ${ }^{1}$, Я.І. Семенов ${ }^{1}$ \\ ${ }^{1}$ Харківський наиіональний університет Повітряних Сил ім. І. Кожедуба, Харків \\ ${ }^{2}$ АТ “ФЕД”, Харків
}

\title{
ПОРІВНЯЛЬНА ОЦІНКА ТЕХНОЛОГІЧНИХ МЕТОДІВ ЦЕМЕНТАЦІЇ ТА ІОННО-ПЛАЗМОВОГО АЗОТУВАННЯ ПРИ ЇХ ВИКОРИСТАННІ ДЛЯ ЗМІЦНЕННЯ ВИСОКОНАВАНТАЖЕНИХ ВУЗЛІВ АВІАЦІЙНОЇ ТЕХНІКИ
}

У статті представлені результати порівняльної оцінки технологічних методів цементації та іонноплазмового азотування при їх використанні для зміинення високонавантажених вузлів авіаційної техніки. Оичінка проводилася порівнянням контактної втомної міџності при проведенні довготривалих випробувань при терті кочення з проковзуванням поверхонь, змічнених традиційною газовою цементацією $і$ іонноплазмовим азотуванням по технології “АВІНІТ N” (АТ “ФЕД”). Експерименти проводились на машині тертя 2070 СМТ-1 на зразках, виготовлених з жаромічної сталі 20ХЗМВФ ГОСТ 20072.

Ключові слова: випробування при терті кочення, втомна міџність, довготривалі випробування, порівняльні випробування, зміцнення поверхонь тертя цеементацією, зміцнення поверхонь тертя азотуванням, іонно-плазмове азотування, кочення з проковзуванням, технологія зміцнення “АВIНIT N”.

\section{Вступ}

Постановка проблеми. Ресурс роботи деталей різних пристроїв та агрегатів в ряді випадків визначається здатністю матеріалу протистояти втомному руйнуванню, яка характеризується величиною контактної міцності матеріалу. Серед методів, які використовуються для підвищення контактної міцності матеріалів, широко використовуються хімікотермічні методи цементації поверхні металів. Методи азотування також використовуються, хоча і менш часто, ніж цементація. Це пов'язано з традиційним уявленням про перевагу цементації перед азотуванням у формуванні зміцнених шарів великої протяжності як одного 3 основних факторів, 3 яким пов'язують підвищення контактної міцності. Таке уявлення створилося давно при співставленні результатів розповсюджених звичайних методів цементації та газового пічного азотування.

Але на даний час розроблені і застосовуються нові методи азотування, які мають значні переваги над цементацією. Але для оцінки експлуатаційних показників конструкційних матеріалів, зміцнених за новими методами, необхідно проведення довготривалих випробувань на втомну міцність на машинах тертя, які моделюють роботу таких спряжень.

Аналіз останніх досліджень і публікацій. Такий стан питання обумовлює обмежену кількість досліджень по впливу азотування на величину контактної міцності матеріалів, особливо іонноплазмовими методами азотування, які мають істотні відмінності та переваги перед традиційними пічними методами газового азотування [1-8], а саме:
- значне скорочення (у 2-3 рази) часу дифузійного насичення азотом поверхневого шару сплавів на основі заліза при загальному скороченні часу технологічного циклу обробки до 3-5 разів;

- дозволяють повністю уникнути водневого окрихчування та інше.

Впродовж багатьох років в Україні проводяться інтенсивні дослідження і розробки багатокомпонентних багатофункціональних покриттів та методів їх нанесення на поверхні 3 прецизійною обробкою, яку потребують деталі вузлів сучасних агрегатів літакобудування, космічної техніки та інших галузей [710]. Такі ж дослідження проводяться і за кордоном [11-14]. Такі поверхні мають шорсткість не гірше 12 класу чистоти обробки, допуски в розмірах на рівні 1 мкм і менше і у більшості випадків не можуть доопрацьовуватись після нанесення покриття, що потребує розробки спеціальних методів нанесення покриттів, які могли б забезпечити такі вимоги. Результатом є розроблена на АТ “ФЕД” технологія зміцнюючого іонно-плазмового азотування “АВІНІТ N” [6-8], сутність якої полягає в тому, що на поверхні виробу формується азотований шар зі стабільно рівноважною мікроструктурою без тендітної поверхневої структури i, як наслідок, збільшується твердість, відсутнє викривлення виробів, забезпечується збереження вихідних геометричних розмірів при одночасному прискоренні азотування в 3-5 разів.

Головною перевагою, яка декларується в патенті і вимагає підтвердження, є можливість отримання спеціальної контрольованої структури поверхневих шарів металів для конкретних умов роботи трибосистем [7-8]. 
Авторами статті на першому етапі досліджень проводилися прискорені випробування 3 використанням методу акустичної емісії (AE) за спеціально розробленою методикою [15]. За цими дослідженнями у якості критерію оцінки втомної міцності було запропоновано використовувати питому енергію дисипації за один цикл навантаження $\bar{E}_{\text {дис }}$. За цим критерієм зразки 3 азотуванням мають значну (більш, ніж в 2 рази) перевагу перед цементованими. Ці дослідження дали підгрунтя для проведення повноцінних довготривалих випробувань, необхідних для впровадження іонно-плазмового методу для зміцнення реальних агрегатів авіаційної техніки.

Актуальність даної роботи обумовлена рішенням ДП “Антонов” про розробку дослідних зразків приводів генераторів для літаків сімейства Ан148/158/178 зі збільшеним до 12000 годин ресурсом без ремонту, що потребувало заміни традиційного методу зміцнення зубів шестерень цементацією на новий, більш досконалий метод зміцнення - іонноплазмове азотування. Для цього виникла необхідність у проведенні комплексних випробувань на втому та докладних металофізичних та рентгеноструктурних досліджень.

Метою роботи $\epsilon$ порівняльна оцінка експлуатаційних показників втомної міцності зразків, моделюючих роботу високонавантажених агрегатів авіаційної техніки при зміцненні їх поверхневого шару традиційною цементацією та перспективним методом іонно-плазмового азотування.

\section{Виклад основного матеріалу}

Випробування проводилися на порівняння контактної втомної міцності при терті кочення з проковзуванням поверхонь, зміцнених традиційною газовою цементацією і іонно-плазмовим азотуванням по технології АВІНІТ N (АТ “ФЕД”).

У даній роботі, після проведення модернізації машини тертя, вдалося досягти контактних навантажень, що дозволяють оцінити відносну контактну втому при циклічних навантаженнях в умовах кочення $з$ проковзуванням. У цих дослідженнях зразки зі зміцненням цементацією прийняті за еталон.

Випробування проведені в Харківському національному університеті ПС ім. І. Кожедуба на підставі договору про науково-технічне співробітництво з підприємством АТ “ФЕД”.

Випробування проводили на вдосконаленій машині тертя 2070 СМТ-1. Схема випробувань “диск-диск”. Змащення здійснювалася маслом М-8В ГОСТ 10541 шляхом занурення нижнього зразка в масляну ванну. Температуру в зоні контакту вимірювали пірометром “Нимбус-760”. Об'єктами випробувань були зразки у вигляді дисків діаметром 50 мм і висотою 12 мм - стандартні для машин тертя СМЦ-2 і 2070 СМТ-1.
Випробували зразки з одного матеріалу - сталь 20ХЗМВФ ГОСТ 20072-74. Марка матеріалу обрана 3 умови, що дана сталь може зміцнюватися як цементацією, так і азотуванням.

Для порівняння контактуючі поверхні зразків були зміцнені газовою цементацією за традиційною технологією, шліфовані після загартування та азотуванням “АВIHIT N” [7-8].

Випробувано по чотири однойменних пари тертя. Умови випробувань: швидкість обертання ведучого зразка - 500 об/хв; прослизання між зразками $20 \%$; абсолютне навантаження - 4500 Н (розрахункове питоме контактне навантаження $\sigma_{\max }=1400 \mathrm{MПа),} \mathrm{швидкість} \mathrm{навантаження} \mathrm{-} 450 \mathrm{H} / \mathrm{c}$; час досягнення навантаження - 10 секунд; час випробувань - 32 години роботи періодами по 8 годин з 16 годинними перервами, що відповідало 960000 циклів.

Результати довготривалих випробувань на втомну міцність.

У якості оціночного показника було прийнято ваговий знос за весь період випробувань. В даному випадку оцінювалася інтегральна характеристика зносостійкості в умовах великих контактних напружень. Дана характеристика включала втрату маси через нормальний механохімічний знос і за рахунок втомного викришування. В таких умовах випробувань розділити ці дві складові зношування не представляється можливим.

Випробували по три пари тертя 3 певними номерами. Результати наведені в табл. 1-2. Явищ задиру не виявлено за весь період випробувань на жодній парі зразків.

Під час випробувань реєстрували середньоповерхневу температуру і момент тертя, який перераховувався в коефіцієнт тертя (табл. 1).

Таблиця 1

Результати вимірювання коефіцієнту тертя і температури

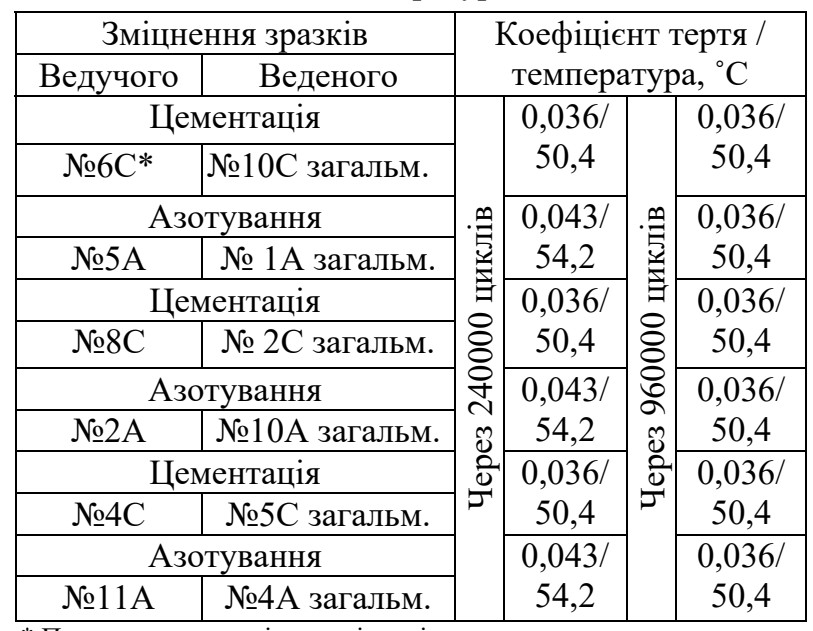

* Позначення номерів зразків, які в подальшому використовувалися для металофізичних досліджень. 
До і після випробувань зразки зважували на аналітичних лабораторних терезах ВЛА-200 з точністю до $10^{-4}$ гр. Визначали знос ведучого і веденого зразків, а також сумарний знос (табл. 2).

В момент відділення великої частки зносу за механізмом піттингу на діаграмі зміни коефіцієнта тертя спостерігається стрибок, тривалість якого 10-12 хв. На наш погляд, це обумовлено механікою руйнування. Спочатку відбувається випинання, а потім - відділення обсягу матеріалу (рис. 1). Після чого момент тертя стабілізується і починається вищерблення по межі дефекту. Таким чином поступово утворюється характерна полосчатість на зразках 3 цементацією.

Таблиця 2

Результати визначення вагового зносу зразків

\begin{tabular}{|c|c|c|c|}
\hline \multirow[b]{2}{*}{$\begin{array}{c}\text { Зміцнення } \\
\text { зразків }\end{array}$} & \multicolumn{2}{|c|}{ Ваговий знос зразків, гр } & \multirow[b]{2}{*}{$\begin{array}{c}\text { Сумарний } \\
\text { знос, гр }\end{array}$} \\
\hline & $\begin{array}{l}\text { Ведучих } \\
\text { (нижніх) }\end{array}$ & $\begin{array}{l}\text { Ведених } \\
\text { (верхніх) }\end{array}$ & \\
\hline Цементація/ & $6 C-0,1816$ & $10 \mathrm{C}-0,1052$ & 0,2868 \\
\hline \multirow[t]{2}{*}{ Цементація } & $8 C-0,1690$ & $2 \mathrm{C}-0,1163$ & 0,2853 \\
\hline & $4 C-0,2004$ & $5 C-0,1105$ & 0,3109 \\
\hline \multirow{2}{*}{$\begin{array}{c}\text { Всього/ } \\
\text { середнє за } 3 \\
\text { зразка }\end{array}$} & $0,551 /$ & $0,332 /$ & $0,883 /$ \\
\hline & 0,1837 & 0,1107 & 0,2943 \\
\hline \multirow{3}{*}{$\begin{array}{l}\text { Азотування } \\
\text { Азотування }\end{array}$} & $5 A-0,0164$ & $1 \mathrm{~A}-0,0104$ & \multirow{3}{*}{0,0268} \\
\hline & $2 \mathrm{~A}-0,0185$ & $10 \mathrm{~A}-0,0132$ & \\
\hline & $4 \mathrm{~A}-0,0163$ & $11 \mathrm{~A}-0,0122$ & \\
\hline $\begin{array}{c}\text { Всього/ } \\
\text { середнє за } 3 \\
\text { зразка }\end{array}$ & $\begin{array}{c}0,0512 / \\
0,0171\end{array}$ & $\begin{array}{c}0,0358 / \\
0,0119\end{array}$ & $\begin{array}{l}0,087 / \\
0,029\end{array}$ \\
\hline
\end{tabular}

Отримані дані свідчать про те, що зразки, зміцнені азотуванням за технологією [6-8], мають більш високі показники зносостійкості в порівнянні з цементацією з урахуванням втомного механізму поверхневого руйнування (в 10 разів).

Також фрактографічні дослідження показують (рис. 2), що на поверхнях тертя спостерігаються локальні викришування втомного характеру (для азотованих зразків глибиною в межах 0,006...0,009 мм, для цементованих - глибина збільшується до 0,015...0,03 мм). Аналіз мікрофотографій поверхонь і візуальне спостереження по всій поверхні зразків показав, що ведучий ролик з цементацією втрачає вагу в основному в результаті втомних пошкоджень і частково за рахунок механохімічного зносу. У веденого ролика втрата ваги в основному відбувається за рахунок нормального механохімічного зносу i частково - втомного.

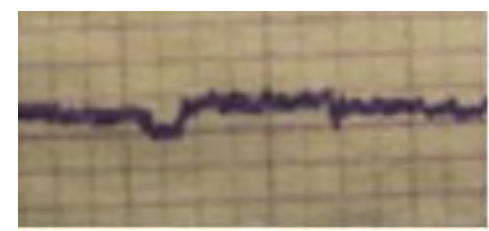

Рис. 1. Момент тертя при піттинговому руйнуванні поверхневого шару цементованого зразку
Причому, глибина пошкоджень в цьому випадку значно більше (рис. 2, а-б). У азотованих зразків втрата ваги для ведучого і веденого зразків виникає рівноцінно за рахунок механохімічного зносу і втомних пошкоджень (рис. 2, в-г).
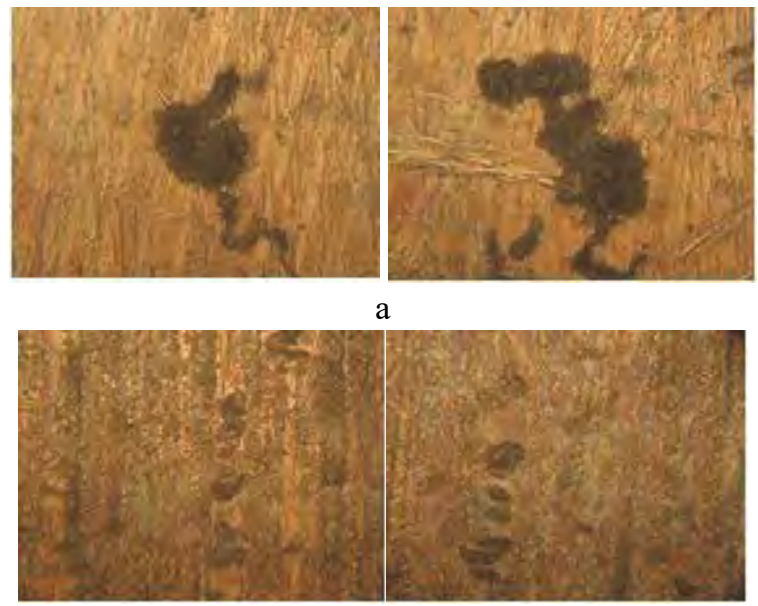

6

Рис. 2. Фрактографічні дослідження поверхонь тертя після випробувань (×534): а - зміцнення цементацією, б - зміцнення азотуванням

Для підтвердження гіпотези причин переваг структурної інженерії поверхні з азотуванням перед поверхнею $з$ цементацією, були проведені вимірювання мікротвердості по глибині поверхневого шару в діапазоні до 0,2 мм (табл. 3-4) [15] і коерцитивної сили ${ }^{1}$ [16] (табл. 5). Дослідження проводили до випробувань і після 32 годин напрацювання.

Проводячи аналіз цих результатів, можна зробити наступний висновок: в цементованому шарі після 960000 циклів спостерігається значне зниження мікротвердості за рахунок накопичення в поверхневому шарі втомних дефектів мікроструктурного рівня. Це і $є$ причиною підвищення інтегральної величини зносу (звичайний механохімічний знос плюс пітингові руйнування).

Для зразків із азотуванням значення мікротвердості залишаються практично на тому ж рівні, що $є$ підтвердженням аморфізації поверхневого шару, i, внаслідок цього, значно меншого накопичення втомних дефектів.

Вимірювання коерцитивної сили (табл. 6) також підтверджують ці висновки: кількість границь зерен в мікроструктурі цементованого шару зростає, а у азотованого - навіть дещо зменшується за рахунок аморфізації поверхневого шару в процесі тривалої роботи. Це досить добре спостерігається на мікрошліфах, представлених далі.

${ }^{1}$ Коерцитиметрія є доволі ефективним методом неруйнівного контролю. Вона дозволяє за вимірюваннями магнітної характеристики металу - коерцитивної сили - судити про механічні властивості, напружено-деформований стан та ступінь втомленості матеріалу [16]. 
Результати визначення мікротвердості $H_{\mu}$ до випробувань

\begin{tabular}{|c|c|c|c|c|c|c|c|c|c|}
\hline \multirow{3}{*}{ № зразку } & \multicolumn{9}{|c|}{ Навантаження $P, \mathrm{H}$} \\
\hline & 0,5 & 1,0 & 2,0 & 0,5 & 1,0 & 2,0 & 0,5 & 1,0 & 2,0 \\
\hline & \multicolumn{3}{|c|}{ Діагональ відбитку $d$, мкм } & \multicolumn{3}{|c|}{ Глибина відбитку $h$, мкм } & \multicolumn{3}{|c|}{ Мікротвердість $H_{\mu}$, кг/мм² } \\
\hline 6А (азотування) & 9,4 & 12,7 & 17,7 & 1,34 & 1,81 & 2,53 & 1049 & 1149 & 1184 \\
\hline 7С (цементація) & 21,2 & 24,0 & 24,6 & 3,02 & 3,43 & 3,52 & 780 & 1060 & 1160 \\
\hline
\end{tabular}

Таблиця 4

Результати визначення мікротвердості $H_{\mu}$ після випробувань 3960000 циклів навантаження (32 години роботи з робочим проміжком по 8 годин на добу)

\begin{tabular}{|c|c|c|c|c|c|c|c|c|c|}
\hline \multirow{3}{*}{ № зразку } & \multicolumn{9}{|c|}{ Навантаження $P, \mathrm{H}$} \\
\hline & 0,5 & 1,0 & 2,0 & 0,5 & 1,0 & 2,0 & 0,5 & 1,0 & 2,0 \\
\hline & \multicolumn{3}{|c|}{ Діагональ відбитку $d$, мкм } & \multicolumn{3}{|c|}{ Глибина відбитку $h$, мкм } & \multicolumn{3}{|c|}{ 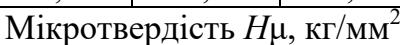 } \\
\hline 4А (азотування) & 10,3 & 12,0 & 17,9 & 1,5 & 1,7 & 26 & 873 & 1287 & 1157 \\
\hline 5С (цементація) & 11,9 & 16,9 & 22,3 & 1,7 & 2,4 & 3,2 & 655 & 649 & 746 \\
\hline
\end{tabular}

Таблиця 5

Результати визначення коерцитивної сили

\begin{tabular}{|c|c|c|}
\hline \multirow{2}{*}{$\begin{array}{c}\text { Спосіб } \\
\text { зміцнення }\end{array}$} & \multicolumn{2}{|c|}{$\begin{array}{c}\text { Значення коерцитивної сили } \\
H_{c}, \mathrm{~A} / \mathrm{cm}\end{array}$} \\
\cline { 1 - 3 } & $\begin{array}{c}\text { до випробу- } \\
\text { вань }\end{array}$ & $\begin{array}{c}\text { Після 32 годин } \\
\text { випробувань }\end{array}$ \\
\hline Цементація & 20,6 & 26,2 \\
\hline Азотування & 10,2 & 8,0 \\
\hline
\end{tabular}

Таким чином, результати порівняльних випробувань показали суттєву перевагу зразків, що мають зміцнення азотуванням у порівнянні з цементацією. За показниками коефіцієнта тертя трибосистема зі зміцненням азотуванням кілька поступається трибосистемі з цементацією в першому циклі роботи (8 год). Це, мабуть, пов'язано з появою в процесі роботи на поверхнях зразків з цементацією характерного “полосчатого” рельєфу. Після 32 годин випробувань коефіцієнти тертя для обох досліджуваних трибосистем вирівнюються (табл. 1). Інтегральна величина величини зносу зразків, зміцнених азотуванням, більш ніж в 10 разів менше в порівнянні зі зміцненням цементацією.

Дослідження роликів 6С/10C (цементація) та 5A/1A (азотування) виконані фахівцями і на обладнанні АТ “Мотор Січ” (Запоріжжя, Україна). Огляд зразків 6C і 10C за допомогою бінокулярного та оптичного мікроскопів встановив, що рельєф прикатаних поверхонь $\epsilon$ характерним для тертя з проковзуванням, яке супроводжується утворенням поверхневих рисок та заглибин у вигляді точкових раковин на всіх ділянках, які брали участь у контакті. Огляд зразків 5A і 1A за допомогою бінокулярного та оптичного мікроскопів встановив, що на їх поверхнях проглядається рельєф вихідної механічної обробки з наявністю рисок та заглибин у вигляді точкових раковин, характерних для поверхневого відлущування та викришування, на всіх ділянках, які брали участь у контакті. Для підтвердження характеру ра- ковин на поверхнях зразків зроблено фрактографічне дослідження за допомогою електронного мікроскопа при збільшенні до х5500. В результаті підтверджено, що раковини являють собою сліди втомного відлущування і викришування: по денцях раковин спостерігаються лінії відпочинку, характерні для втомного руйнування (рис. 3).
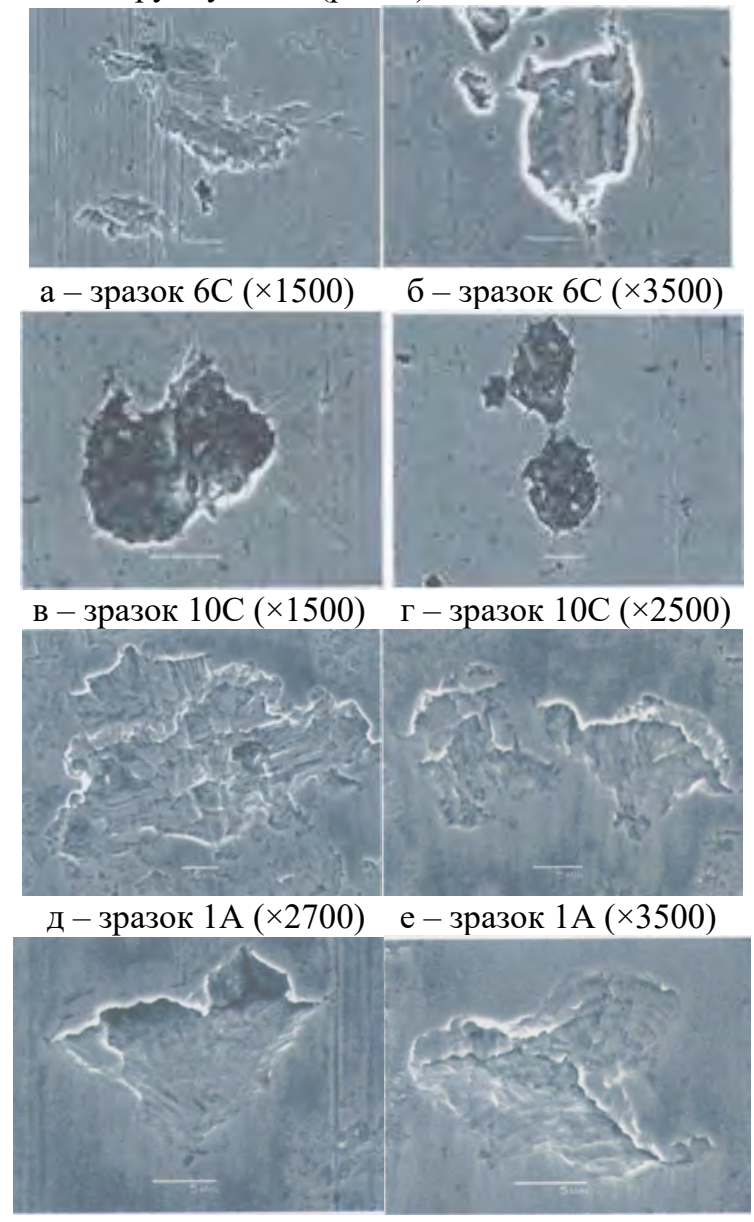

ж - зразок 5А $(\times 4500)$ е - зразок 5А $(\times 5000)$

Рис. 3. Фрактографічні дослідження: а - зразок 6С $(\times 1500) ;$ б - зразок 6С $(\times 3500)$; в - зразок $10 \mathrm{C}$ $(\times 1500) ;$ г - зразок 10C $(\times 2500)$; д - зразок $1 \mathrm{~A}$ $(\times 2700)$; е - зразок $1 \mathrm{~A}(\times 3500)$ 
Мікродослідженням поперечних шліфів (рис. 4-5) встановлено, що глибина лунок від викришування складає:

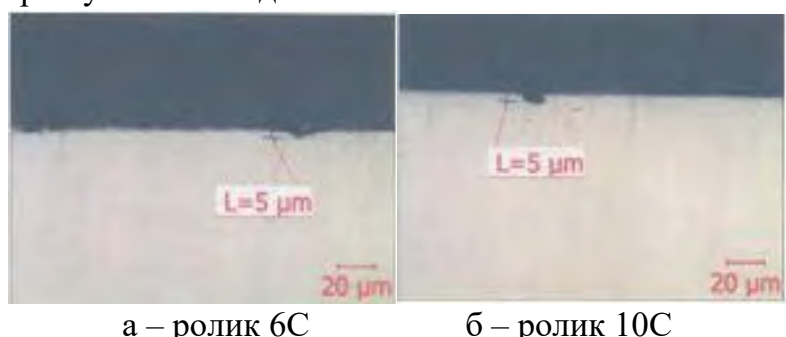

Рис. 4. Глибина лунок від викришування цементованих зразків:

$\mathrm{a}$ - ролик $6 \mathrm{C}, 6$ - ролик $10 \mathrm{C}$

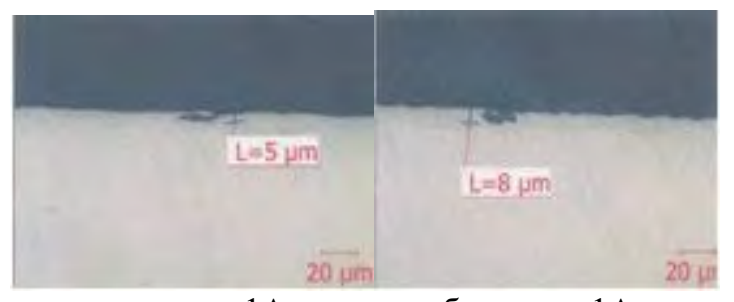

$\mathrm{a}-$ ролик $1 \mathrm{~A} \quad$ б-ролик $1 \mathrm{~A}$

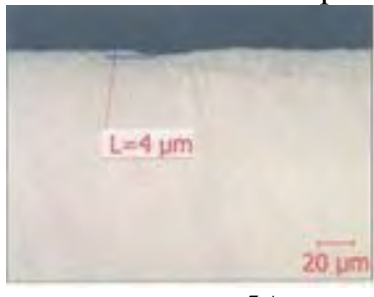

в - ролик $5 \mathrm{~A}$

Рис. 5. Глибина лунок від викришування азотованих зразків: а, б - ролик $1 \mathrm{~A}$, в - ролик $5 \mathrm{~A}$
- на цементованих зразках 6С та $10 \mathrm{C}$ фактично однакова і складає $\approx 5$ мкм (рис. 4, а-б);

- на азотованих зразках $5 \mathrm{~A}$ та $1 \mathrm{~A}$ фактично однакова і складає $\approx 4$...5 мкм, одиничних лунок - до 8 мкм (рис. 5, а-в).

\section{Висновки}

Результати довготривалих випробувань на базі 1 млн. циклів (кочення 3 20\%-м проковзуванням 3 контактним навантаженням $\sigma_{\max }=1400$ МПа, характерним для середньо- та високонавантажених поверхонь) показали, що інтегральна багатоциклова стійкість до втомного зношування (руйнування) зразків, зміцнених азотуванням (іонно-плазмове азотування “АВIHIT N” з глибиною шару 0,25 мм), в 10 разів вище, ніж у зразків, зміцнених цементацією (з глибиною шару 1,2 мм).

Результати досліджень можуть бути основою для проведення дослідних робіт з ідентифікації фазового складу поверхневого шару азотованих зразків.

На основі таких досліджень в подальшому можливе впровадження та використання іонноплазмових технологій азотування замість цементування $з$ метою збільшення контактної міцності поверхонь деталей, приймаючи до уваги також такі переваги азотування, як збереження розмірів та високої чистоти обробки поверхонь, внаслідок чого відпадає необхідність їх механічної доробки після зміцнення.

\section{Список літератури}

1. Азотный потенциал: современное состояние проблемы и концепция развития / В.М. Зинченко, В.Я. Сыропятов, Б.А. Прусаков, Ю.А. Перекатов. - М.: Машиностроение, 2003. - 90 с.

2. Пастух I.М. Вплив режимних параметрів азотування у тліючому розряді на товщину нітридної зони модифікованого шару / І.М. Пастух, Г.М. Соколова, О.С. Здибель // Вісник Хмельницького національного університету. - 2014. № 4(215). - C. 130-134.

3. Могильная Е.П. Ионное азотирование изделий из конструкционной стали 38ХМФА / Е.П. Могильная, В.М. Дубасов // Ресурсозберігаючі технології виробництва та обробки тиском матеріалів у машинобудуванні. - 2013. № 1. - С. 193-198.

4. Костик К.О. Порівняльний аналіз впливу газового та іонно-плазмового азотування на зміну структури і властивості легованої сталі 30Х3ВА / К.О. Костик, В.О. Костик // Вісник Національно-технічного університету “ХПІ”. - Х.: НТУ “ХПІ”. - 2014. - № 48(1090). - С. 21-41.

5. Сагалович А.В. Автоматизированная система нанесения функциональных нанопокрытий / А.В. Сагалович, С.Ф. Дудник, В.В. Сагалович // Оборудование и инструмент. - 2005. - Т. 12. - С. 2-3.

6. Сагалович О.В., Сагалович В.В. Спосіб іонно-плазмового прецизійного азотування поверхонь сталей та сплавів Avinit N. Pat. UA № 84664 від 25.10.13.

7. Сагалович О.В., Сагалович В.В. Спосіб іонно-плазмового прецизійного азотування поверхонь сталей та сплавів Avinit N. Pat. UA №107408 від 28.12.14.

8. Sagalovich V.V., Sagalovich, A.V. The method of ion-plasma precision nitriding of the surfaces of metal products, Patent 2555692, Russian Federation, C23C8/36 (H01J 37/00), C23C14/48, stated 27.12.2014; publ. 10.07.2015, Bull. No. 19, 13 p.

9. Разработка многокомпонентных покрытий для повышения износостойкости поверхностей пар трения в прецизионных узлах / А.В. Сагалович, С.Ф. Дудник, В.В. Сагалович, А.В. Кононыхин, В.В. Попов, А.П. Любченко, А.К. Олейник // Физическая инженерия поверхности. - 2007. - Т. 5, № 3-4. - С. 155-164.

10. Исследование характеристик трения и износа ионно-плазменных покрытий, полученных на алюминиевом сплаве / С.Ф. Дудник, А.В. Сагалович, В.В. Сагалович, А.П. Любченко, А.К. Олейник // Физическая инженерия поверхности. - 2004. - № 1(2). - С. 110-114. 
11. Amiri M. On the thermodynamics of friction and wear - a review / M. Amiri, M.M. Khonsari // Entropy. - 2010. Vol. 12. - P. 1021-1049.

12. Research on friction-coatings with activated ultra-thick tin-base / M. Yunhui, T. Dehua, W. Xicheng, L. Qinghua // Advanced Tribology. - 2010. - P. 915-919.

13. Problems of Kinetics of Surface Destruction / D.G. Gromakovsky, A.G. Kovshov, I.D. Ibatullin, A.V. Dynnikov // Proceedings of VII-th International Symposium "INTERTRIBO 2002", section B - Wear. - Slovak Republic, Stara Lesna: House of Technology, 2002. - P. 57-58.

14. Gromakovsky D.G. Modelling and Wear Calculation on Friction / D.G. Gromakovsky, A.N. Malyarov, Y.P Samarin // Absrtacts of Papers of the World Tribology Congress. - Bath, UK: Bookcraft Limited, 1997. - 462 p.

15. Стадниченко В.М. Методика прискореної оцінки показників втомної пошкоджуваності конструкційних матеріалів / В.М. Стадниченко, Р.М. Джус, С.А. Плешкунов // Системи озброєння і військова техніка. - 2019. - № 2(58). C. 122-131. https://doi.org/10.30748/soivt.2019.58.15.

16. Texture and coercive force of the metal of furnace tube coils / N.M. Shkatulyak, E.A. Dragomeretskaya, V.V. Usov, M.D. Rabkina, A.L. Palienko // Diagnostics, Resource and Mechanics of materials and structures. - 2016. - Issue 1. - P. 29-37. https://doi.org/10.17804/2410-9908.2016.1.029-037.

\section{References}

1. Zynchenko, V.M., Syropiatov, V.Ya., Prusakov, B.A. and Perekatov, Yu.A. (2003), "Azotnyi potentsyal: sovremennoe sostoianye problemy y kontseptsyia razvytyia" [Nitrogen potential: current state of the problem and concept of development], Engineering, Moscow, 90 p.

2. Pastukh, I.M., Sokolova, H.M. and Zdybel, O.S. (2014), "Vplyv rezhymnykh parametriv azotuvannia u tliiuchomu rozriadi na tovshchynu nitrydnoi zony modyfikovanoho sharu" [Influence of nitriding in a glow discharge operational parameters on the nitride zone of the modified layer thickness], Herald of Khmelnytskyi National University, No. 4(215), pp. 130-134.

3. Mogilnaya, E.P. and Dubasov, V.M. (2013), "Yonnoe azotyrovanye yzdelyi yz konstruktsyonnoi staly 38KhMFA" [Ionic nitriding of wares from the structural steel 38XMFA], Resource Processing Technology and Processing With the help of Clamping Materials at the Machine, No. 1, pp. 193-198.

4. Kostik, K.O. and Kostik, V.O. (2014), "Porivnialnyi analiz vplyvu hazovoho ta ionno-plazmovoho azotuvannia na zminu struktury i vlastyvosti lehovanoi stali 30Kh3VA" [Particular analysis of gas and ion-plasma nitrogen inflow to winter structure and power of alloy steel 30X3VA], Bulletin of the National Technical University “KPI”, No. 48(1090), pp. 21-41.

5. Sagalovich, A.V., Dudnik, S.F. and Sagalovich, V.V. (2005), "Avtomatizirovannaya sistema naneseniya funktsionalnyih nanopokryitiy" [Automated system for applying functional nanocoatings], Equipment and Tools, Vol. 12, pp. 2-3.

6. Sagalovich, A.V. and Sagalovich, V.V. (2013), "Sposib ionno-plazmovoho pretsyziinoho azotuvannia poverkhon stalei ta splaviv Avinit $N$ " [Method for ion-plasma precision nitriding of steels and alloys surfaces Avinit N], Pat. UA No.84664 25.10.13., bull. No. 14, 13 p.

7. Sagalovich, A.V. and Sagalovich, V.V. (2013), "Sposib ionno-plazmovoho pretsyziinoho azotuvannia poverkhon stalei ta splaviv Avinit $N$ " [Method for ion-plasma precision nitriding of steels and alloys surfaces Avinit $N$ ], Pat. UA No.107408 28.12.14., bull. No. 15,14 p.

8. Sagalovich, V.V. and Sagalovich, A.V. (2014), "Sposob ionno-plazmennogo pretsizionnogo azotirovaniya poverhnostey metallicheskih izdeliy" [The method of ion-plasma precision nitriding of the surfaces of metal products], Patent 2555692, Russian Federation, C23C8/36 (H01J 37/00), C23C14/48, stated 27.12.2014; publ. 10.07.2015, bull. No. 19, 13 p.

9. Sagalovich, A.V., Dudnik, S.F., Sagalovich, V.V., Kononykhin, A.V., Popov, V.V., Lubchenko, A.P. and Oleynik, A.K. (2007), "Razrabotka mnogokomponentnyih pokryitiy dlya povyisheniya iznosostoykosti poverhnostey par treniya v pretsizionnyih uzlah" [Development of multicomponent coatings to increase the wear resistance of surfaces of friction pairs in precision units], Physical Surface Engineering, Vol. 5, No. 3-4, pp. 155-164.

10. Dudnik, S.F., Lubchenko, A.P., Oleynik, A.K., Sagalovich, A.V. and Sagalovich, V.V. (2004), "Issledovanie harakteristik treniya i iznosa ionno-plazmennyih pokryitiy, poluchennyih na alyuminievom splave" [The investigation of friction and wear characteristics of ion-plasma coatings, received on the aluminum alloy], Physical Surface Engineering, Vol. 2, No. 1-2, pp. 110-114.

11. Amiri, M. and Khonsari, M.M. (2010), On the thermodynamics of friction and wear - a review, Entropy, Vol. 12, pp. 1021-1049.

12. Yunhui, M., Dehua, T., Xicheng, W. and Qinghua, L. (2010), Research on friction-coatings with activated ultra-thick tin-base, Advanced Tribology, pp. 915-919.

13. Gromakovsky, D.G., Kovshov, A.G., Ibatullin, I.D. and Dynnikov, A.V. (2002), Problems of Kinetics of Surface Destruction, Proceedings of VII-th International Symposium “INTERTRIBO 2002”, section B - Wear, House of Technology, Slovak Republic, Stara Lesna, pp. 57-58.

14. Gromakovsky, D.G., Malyarov, A.N. and Samarin, Y.P. (1997), Modeling and Wear Calculation on Friction, Abstracts of Papers of the World Tribology Congress, Bookcraft Limited, Bath, UK, $462 \mathrm{p}$.

15. Stadnychenko, V.M., Dzhus, R.M. and Pleshkunov, S.A. (2019), "Metodyka pryskorenoi otsinky pokaznykiv vtomnoi poshkodzhuvanosti konstruktsiinykh materialiv" [Method of accuracy assessment of performance indicators of construction materials], Systems of Arms and Military Equipment, No. 2(58), pp. 122-131, https://doi.org/10.30748/soivt.2019.58.15. 
16. Shkatulyak, N.M., Dragomeretskaya, E.A., Usov, V.V., Rabkina, M.D. and Palienko, A.L. (2016), Texture and coercive force of the metal of furnace tube coils, Diagnostics, Resource and Mechanics of Materials and Structures, Iss. 1, pp. 29-37. https://doi.org/10.17804/2410-9908.2016.1.029-037.

Відомості про авторів:

Джус Роман Миколайович

кандидат технічних наук

старший науковий співробітник

старший викладач

Харківського національного університету

Повітряних Сил ім. І. Кожедуба,

Харків, Україна

https://orcid.org/0000-0002-7079-0912

\section{Стадніченко Микола Григорович}

кандидат технічних наук доцент

старший викладач

Харківського національного університету

Повітряних Сил ім. І. Кожедуба,

Харків, Україна

https://orcid.org/0000-0003-4613-6256

\section{Попов Віктор Васильович}

кандидат технічних наук

Голова правління АТ “ФЕД”,

Харків, Україна

https://orcid.org/0000-0001-9189-6882

\section{Плешкунов Сергій Анатолійович}

викладач

Харківського національного університету

Повітряних Сил ім. І. Кожедуба,

Харків, Україна

https://orcid.org/0000-0002-0733-4535

\section{Семенов Ярослав Іванович}

курсант

Харківського національного університету

Повітряних Сил ім. І. Кожедуба,

Харків, Україна

https://orcid.org/0000-0003-1856-2872
Information about the authors:

\author{
Roman Dzhus \\ Candidate of Technical Sciences \\ Senior Research \\ Senior Instructor \\ of Ivan Kozhedub Kharkiv \\ National Air Forces University, \\ Kharkiv, Ukraine \\ https://orcid.org/0000-0002-7079-0912
}

\author{
Mykola Stadnichenko \\ Senior Instructor \\ of Ivan Kozhedub Kharkiv \\ National Air Forces University, \\ Kharkiv, Ukraine \\ https://orcid.org/0000-0003-4613-6256
}

Candidate of Technical Sciences Associate Professor

\author{
Viktor Popov \\ Candidate of Technical Sciences \\ Chairman of the Board of JSC "FED", \\ Kharkiv, Ukraine \\ https://orcid.org/0000-0001-9189-6882
}

\section{Serhii Pleshkunov}

Instructor

of Ivan Kozhedub Kharkiv

National Air Forces University,

Kharkiv, Ukraine

https://orcid.org/0000-0002-0733-4535

\author{
Yaroslav Semenov \\ Cadet \\ of Ivan Kozhedub Kharkiv \\ National Air Forces University, \\ Kharkiv, Ukraine \\ https://orcid.org/0000-0003-1856-2872
}

\title{
СРАВНИТЕЛЬНАЯ ОЦЕНКА ТЕХНОЛОГИЧЕСКИХ МЕТОДОВ ЦЕМЕНТАЦИИ И ИОННО-ПЛАЗМЕННОГО АЗОТИРОВАНИЯ ПРИ ИХ ИСПОЛЬЗОВАНИИ ДЛЯ УПРОЧЕНИЯ ВЫСОКОНАГРУЖЕННЫХ УЗЛОВ АВИАЦИОННОЙ ТЕХНИКИ
}

\author{
Р.Н. Джус, Н.Г. Стадниченко, В.В. Попов, С.А. Плешкунов, Я.И. Семенов
}

В статье представлены результаты сравнительной оценки технологических методов цементации и ионноплазменного азотирования при их использовании для укрепления высоконагруженных узлов авиационной техники. Оиенка проводилась сравнением контактной усталостной прочности при проведении длительных испытаний при трении качения с проскальзыванием поверхностей, усиленных традиционной газовой цементацией и ионно-плазменным азотированием по технологии “АВИНИТ N” (АО “ФЭД”). Эксперименты проводились на машине трения 2070 СМТ 1 в образиах, изготовленных из жаропрочной стали 20ХЗМВФ ГОСТ 20072.

Ключевые слова: испытания при трении качения, усталостная прочность, долговременные испытания, сравнительные испытания, укрепления поверхностей трения цементацией, укрепления поверхностей трения азотированием, ионно-плазменное азотирование, качения с проскальзыванием, технология укрепления “АВИНИТ N”. 


\section{COMPARATIVE ASSESSMENT OF TECHNOLOGICAL METHODS \\ OF CEMENTATION AND ION-PLASMA NITROGEN WHEN USED FOR STRENGTHENING HIGHLY LOADED AERONAUTICAL COMPONENTS}

R. Dzhus, M. Stadnichenko, V. Popov, S. Pleshkunov, Ya. Semenov

Now there are new nitriding methods, which have been developed and are currently being implemented that have significant advantages over cementation. However, long-term fatigue tests on friction machines that model the work of such joints are needed to evaluate the performance of structural materials strengthened by the new methods. The article presents the results of the comparative evaluation of technological methods of cementation and ion-plasma nitriding when used to strengthen high-load units of aviation technology. The evaluation was made by comparing the contact fatigue strength during long-term rolling friction tests with the slip of surfaces strengthened by traditional gas cementation and ion-plasma nitriding using AVINIT N technology (JSC “FED”). The experiments were carried out on a friction machine 2070 CMT 1 on samples made of heat-resistant steel 20X3MVF GOST 20072. The results of long-term tests on the basis of 1 million cycles (rolling with 20\% slip with contact load $\sigma_{\max }=1400 \mathrm{MPa}$, characteristic of medium and high loads ) showed that the integral multicycle resistance to fatigue wear (destruction) of the samples, strengthened by nitriding (ion-plasma nitriding "AVINIT N" with a depth of $0.25 \mathrm{~mm}$ layer), is 10 times higher than that of the samples strengthened by cementation (with the depth of the layer) 1,2 mm). The results of the studies may be the basis for conducting research on the identification of the phase composition of the surface layer of nitrided samples. Based on such studies, it is further possible to introduce and use ion-plasma nitriding technologies instead of cementing in order to increase the contact strength of the surfaces of the parts, taking into account also the advantages of nitriding such as maintaining the dimensions and high purity of the surface treatment, which eliminates the need for their mechanical processing strengthening.

Keywords: rolling friction tests, fatigue strength, long-term tests, comparative tests, strengthening of friction surfaces by cementation, strengthening of friction surfaces by nitriding, ion-plasma nitriding, rolling with slippage, "AVINIT N" hardening technology. 